C.B. Казанський, канд. техн. наук, доц. ORCID 0000-0002-6113-2600

B.I. Моссаковський, асист. ORCID 0000-0002-5096-5957

P.A. Меркотан, магістр ORCID 0000-0002-4813-9656

Національний технічний університет України «Київський політехнічний інститут імені Ігоря Сікорського»

\title{
ДОСЛІДЖЕННЯ КОЛИВАНЬ ПРОВОДІВ ПОВІТРЯНИХ ЛІНІЙ ЕЛЕКТРОПЕРЕДАЧІ 3 УРАХУВАННЯМ ОЖЕЛЕДНО-ВІТРОВИХ НАВАНТАЖЕНЬ
}

В статті розглянуто питання удосконалення процедури побудови моделі коливань проводів повітряних ліній електропередачі в різних режимах вітрових та ожеледних навантажень. Наведено необхідність підвищення експлуатаційної надійності повітряних ліній електропередачі як одного $з$ основних елементів системи передачі електричної енергії. Обгрунтовано доцільність додаткових поглиблених досліджень виникнення складних коливань проводів з різною частотою та амплітудою, які виникають у разі налипання ожеледі, форма якої досить часто не є ідеально ичиліндричною $і$ істотно вливає на зміну коливального процесу. Представлено послідовність моделювання обтікання проводу марки АC 70/11 потоком повітря без урахування та з урахуванням налипання ожеледі різної форми. Наведено результати моделювання, які підтверджують доцільність урахування сили та вектору вітрового потоку, а також форми ожеледi, щзо є визначальними факторами під час визначення амплітуди та частоти коливань. Показано, щүо використання результатів моделювання дозволить істотно підвищити експлуатаційну надійність повітряних ліній електропередачі, особливо напругою від 6 до $35 \kappa B$, розташованих в районах зі значними ожеледно-вітровими навантаженнями.

Ключові слова: повітряні лінії електропередачі, коливання проводів, ожеледно-вітрові навантаження, динамічне моделювання.

Вступ Експлуатаційна надійність систем передавання електричної енергії значною мірою визначається надійністю роботи одного з основних їі елементів - повітряних ліній електропередачі (ПЛ) [1]. Проводи ПЛ незалежно від класу напруги в тій чи іншій мірі схильні до коливань, викликаних дією вітру. Коливання є причиною механічних (пошкодження проводів, лінійної арматури, систем підвісу) та електричних (короткі замикання) аварій, тобто істотного зменшення експлуатаційної надійності ПЛ. 3 результатів експлуатаційних спостережень [2] відомо, що найчастіше коливання проводів ПЛ виникають через вплив дії вітру під час однобічних відкладень у вигляді мокрого снігу, ожеледі або паморозі і тривають від декількох годин до 3 діб. Додатковим чинником виникнення складних коливань проводів ПЛ 3 різною частотою та амплітудою $є$ налипання ожеледі, форма якої досить часто не $є$ ідеально циліндричною і істотно вливає на зміну коливального процесу.

Розрізняють такі види ожеледно-паморозевих відкладень:

- Кристалічна паморозь - білий осад, що складається із кристалів льоду ніжної тонкої структури.

- Зерниста паморозь - снігоподібний пухкий лід матово-білого кольору, що утворюється 3 переохолоджених крапель туману й мряки.

- Ожеледь - шар матового або прозорого льоду, що утворюється під час швидкої зміни погоди 3 переохолодженням крапель туману чи мряки або шляхом осадження переохолодженого дощу.

Найпоширенішими видами коливань проводів, спричинених вітром, є вібрація, галопування проводів під дією вітру за наявності на проводі ожеледі несиметричної форми та коливання проводів розщеплених фаз, що спричинені дією аеродинамічного сліду (так звані субколивання). У [3] надано такі тлумачення зазначених вище понять:

- Вібрація проводів (тросів) - періодичні коливання проводів або тросів у прогоні з частотою від 3 до 150 Гц, які відбуваються у вертикальній площині під час вітру і утворюють стоячі хвилі з розмахом, що може перевищувати діаметр проводів (тросів).

- Галопування проводів (тросів) - сталі періодичні низькочастотні (0,2 - 2 Гц) коливання проводів (тросів) у прогоні, які утворюють стоячі хвилі (іноді в сполученні з біжучими) з числом напівхвиль від однієї до двадцяти та амплітудою $0,3-5$ м.

- Субколивання (коливання проводів у підпрогонах) - викликані вітром періодичні коливання горизонтально розташованої пари проводів розщепленої фази, що відбуваються з однією або декількома напівхвилями на ділянках між сусідніми внутрішньофазними дистанційними розпірками 3 вузловими точками в місцях установки розпірок.

(C) С.В. Казанський, В.І. Моссаковський, Р.А. Меркотан, 2018 
ISSN 1813-5420 (Print). Енергетика: економіка, технологіï, екологія. 2018. № 1

Ступінь впливу деяких факторів може змінюватися в широкому діапазоні від лінії до лінії, але в середньому ці різновиди коливань можуть бути охарактеризовані даними, наведеними у табл. 1.

Таблиця 1 - Порівняння типів коливань проводів ПЛ

\begin{tabular}{|c|c|c|c|}
\hline \multirow[b]{2}{*}{ Типи ПЛ } & Вібрація & Галопування & Субколивання \\
\hline & Будь-який & Будь-який & $\begin{array}{c}\text { ПЛ з розщепленими } \\
\text { фазами }\end{array}$ \\
\hline \multicolumn{4}{|c|}{ Характеристики коливань } \\
\hline $\begin{array}{l}\text { Приблизний діапазон } \\
\text { частот, Гц }\end{array}$ & $3-150$ & $0,08-3$ & $0,15-10$ \\
\hline $\begin{array}{l}\text { Приблизний діапазон } \\
\text { амплітуд коливань (пік- } \\
\text { пік), виражений в значен- } \\
\text { нях діаметра проводу }\end{array}$ & $0,01-1$ & $5-300$ & $\begin{array}{c}\text { Коливання в п/п: } \\
0,5-20 \\
\text { Для фази в цілому: } \\
0,5-80 \\
\end{array}$ \\
\hline \multicolumn{4}{|c|}{ Умови розвитку коливань } \\
\hline Характер вітру & Стійкий & Стійкий & Стійкий, рівний \\
\hline Швидкість вітру, м/с & $1-7$ & $7-18$ & $4-18$ \\
\hline Поверхня проводів & $\begin{array}{c}\text { Голі або з рівномірною } \\
\text { ожеледдю }\end{array}$ & $\begin{array}{c}\text { Несиметричне } \\
\text { відкладення ожеледі }\end{array}$ & Голі, сухі \\
\hline $\begin{array}{l}\text { Розрахункові параметри, } \\
\text { що впливають на рух } \\
\text { проводу }\end{array}$ & $\begin{array}{l}\text { Тяжіння, самодемп- } \\
\text { фірування проводу, } \\
\text { наявність гасників, } \\
\text { спіральної арматури }\end{array}$ & $\begin{array}{c}\text { Відношення верти- } \\
\text { кальної і крутильної } \\
\text { власних частот, стріла } \\
\text { провисання, тип опор }\end{array}$ & $\begin{array}{c}\text { Крок розщеплення, } \\
\text { поворот фази, } \\
\text { розташування проводів у } \\
\text { розщепленій фазі, } \\
\text { довжини підпрогонів } \\
\end{array}$ \\
\hline \multicolumn{4}{|c|}{ Почкодження } \\
\hline $\begin{array}{l}\text { Приблизний час, } \\
\text { необхідний для появи } \\
\text { пошкодження }\end{array}$ & $\begin{array}{l}3 \text { міс }-20 \text { років } \\
\text { і більше }\end{array}$ & $1-48$ годин & $\begin{array}{l}1 \text { міс. }-8 \text { років } \\
\text { і більше }\end{array}$ \\
\hline $\begin{array}{l}\text { Компоненти ПЛ, найбільш } \\
\text { схильні до пошкоджень }\end{array}$ & $\begin{array}{c}\text { Проводи, гасники } \\
\text { вібрації }\end{array}$ & $\begin{array}{c}\text { Проводи, арматура, } \\
\text { ізолятори, траверси, } \\
\text { опори }\end{array}$ & $\begin{array}{c}\text { Підвісна арматура, } \\
\text { розпірки, гасники вібрації, } \\
\text { повиви проводів }\end{array}$ \\
\hline
\end{tabular}

Як зазначено у [2], пошкодженням внаслідок коливань можуть піддаватися всі проводи і троси, що застосовуються на ПЛ незалежно від їхнього матеріалу і перерізу. Спричинені коливаннями пошкодження проводів можуть мати місце за всіх типів застосовуваних у вітчизняній практиці підтримуючих затискачах, у тому числі в затискачах із човником, що хитається, а також і в роликових підвісних пристроях, де провід вільно лежить у канавці ролика. Пошкодження зазвичай концентруються в місцях виходу проводу 3 опорної поверхні ложі затискача або ролика. У натяжних затискачах пошкодження проводів відбуваються значно рідше, ніж у підтримуючих, оскільки на виході з натяжного затискача провід не випробовує статичних напружень вигину.

Під час галопування можуть утворюватись стоячі хвилі з амплітудами від декількох метрів до значень, що досягають стріли провисання проводу. Галопування може тривати від декількох годин до декількох діб і припинятися лише зі зміною метеорологічних умов.

Зважаючи на значні витрати на боротьбу з різними проявами вібрації та великі збитки через наслідки їх дії, у багатьох країнах світу починаючи з 20-х років минулого сторіччя проводяться ретельні дослідження і спостереження за коливаннями проводів. Особливо активно дослідження відбуваються в останні 25 - 30 років. Зокрема під егідою Міжнародної Ради з великих електроенергетичних систем CIGRE (франц.: Conseil International des Grands Reseaux Electriques) проведено низку об'єднуючих засідань, присвячених, у тому числі, питанням боротьби із вібрацією та галопуванням проводів ПЛ. В середньому за кожний рік спостереження галопування спостерігалось протягом приблизно 5,5 дня. Під час галопування проводів, по-перше, виникають переміщення проводів у прогоні, за яких вони можуть виявитися в небезпечній близькості один від одного, що може призвести до пробою ізоляційного проміжку між ними; по-друге, відбувається деформація проводів, особливо в затискачах кріплення проводу до ізоляторів; по-трете, відбувається розгойдування гірлянд ізоляторів, їх деформування, що призводить до втрати міцності окремих іiі елементів і, по-четверте, відбувається не властиве нормальним умовам навантаження опор і особливо траверс, що призводить до деформації або навіть пошкодження елементів опор. Якщо три останніх впливи призводять до поступового, а іноді і швидкого руйнування елементів ПЛ i час від часу вимагають проведення їх ремонту, то перший із впливів призводить до відключення ПЛ i, як наслідок, перерв у електропостачанні споживачів. 


\section{ISSN 1813-5420 (Print). Енергетика: економіка, технології, екологія. 2018. № 1}

Мета статті Із застосуванням програмного пакету SolidWorks дослідити особливості моделювання виникнення коливань проводів ПЛ під дією вітру з урахуванням форми ожеледних навантажень.

Матеріали дослідження Як зазначено вище, коливання $є$ наслідком впливу на провід поперечно спрямованого аеродинамічного потоку, який створює за проводом періодично виникаючі пориви вихрових рухів повітря. Вихрі, що виникають за проводом (рис. 1), несуться повітряними потоками, сприяючи утворенню наступних вихрів із протилежним напрямком обертання. При цьому перехід від ламінарного (спокійного) потоку до турбулентного (завихрення) визначається числом Рейнольда, яке визначається за формулою:

$$
\operatorname{Re}=\frac{V d}{v},
$$

де $V$ - швидкість потоку, м/с; $d$ - діаметр циліндра, м; $v$ - кінематична в'язкість середовища, м $^{2} / \mathrm{c}$. У разі значень $R e=40-150$ виникає нестійкість сліду, зрив, а коли $R e=150-300$, виникає перехід до турбулентності у вихрах.
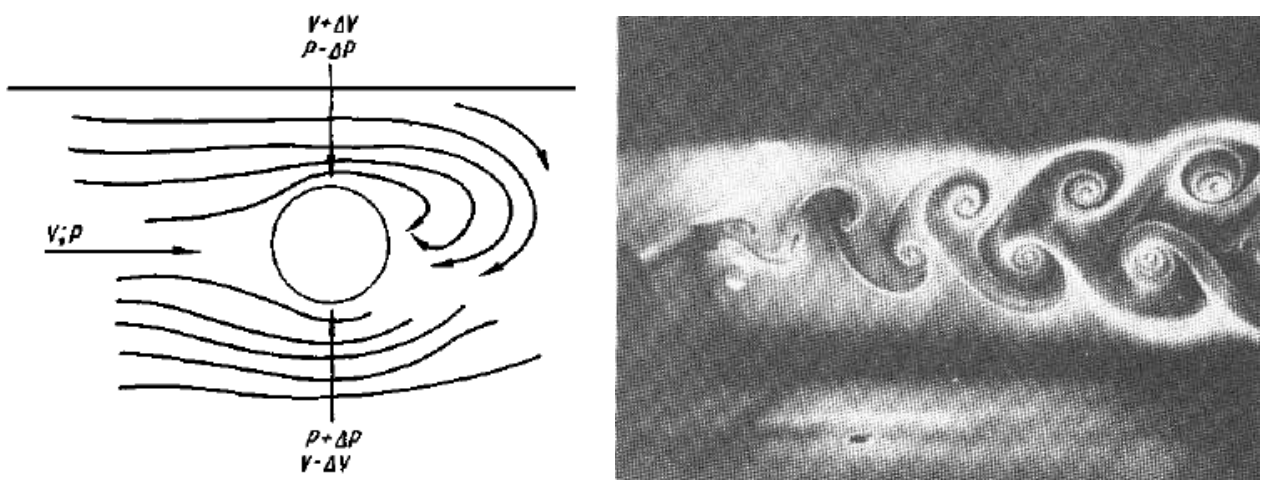

Рисунок 1 - Схема вихроутворення за проводом та вид збоку вихрів, що зриваються з нерухомого циліндра ( $R e=200$, частота зриву вихрів $f=28$ Гц $)$

Взаємозв'язок між швидкістю потоку, діаметром циліндра і частотою вихрів характеризується безрозмірним параметром $S_{t}$ (числом Струхаля):

$$
S_{t}=\frac{v D}{v} .
$$

Для аеродинаміки проводів характерні числа Струхаля зазвичай перебувають в діапазоні від 0,18 до 0,22 , що дає змогу отримати з виразу (2) зручну для практичного використання формулу (3) для визначення частоти утворення вихрів

$$
v=\frac{1000 \cdot S_{t} v}{D} \approx \frac{0,185 \cdot v}{D},
$$

де $v$ - частота утворення вихрів, Гц; $D$ - діаметр проводу, мм; $v$ - швидкість потоку (вітру), м/с. У формулі (3) число Струхаля береться $S_{t}=0,18-0,22$.

Коливання проводів ПЛ, що перебувають під дією вітру, виникають як за відсутності, так і за наявності ожеледних відкладень. Діаграми дії сил вітрового тиску, що спричиняють коливання проводу ПЛ, наведено на рис. 2.

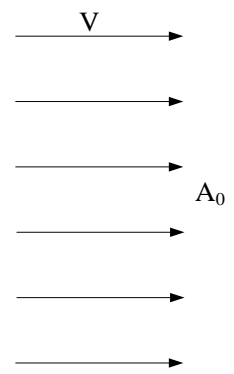

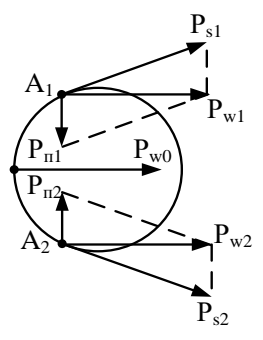

a)

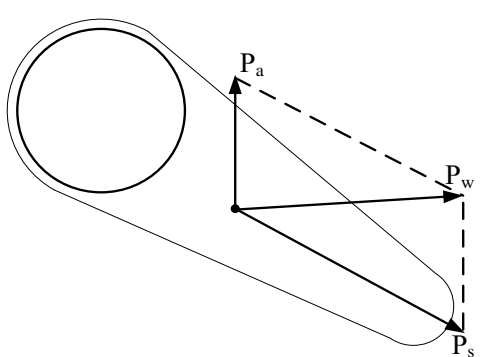

б)

Рисунок 2 - Діаграми дії сил вітрового тиску, що спричиняють коливання проводу ПЛ: а) провід без ожеледі; б) провід з ожеледдю несиметричної форми 
За відсутності ожеледі до кожної точки проводу прикладена сила тиску вітру $P_{w}$, яка має дві складових - вертикальну та повздовжню. 3 аналізу наведеної діаграми сил можна дійти висновку, що у разі рівномірного тиску вітру на провід без ожеледі вертикальні складові сил практично компенсують одна одну, а складові по дотичній будуть сприяти обтіканню проводу потоком повітря.

Набагато складніша картина буде спостерігатися у разі налипання ожеледі, особливо несиметричної форми [2]. Найхарактерніші форми ожеледно-паморозевих відкладень та загальний вигляд проводу ПЛ 3 ожеледдю несиметричної форми наведено на рис. 3.
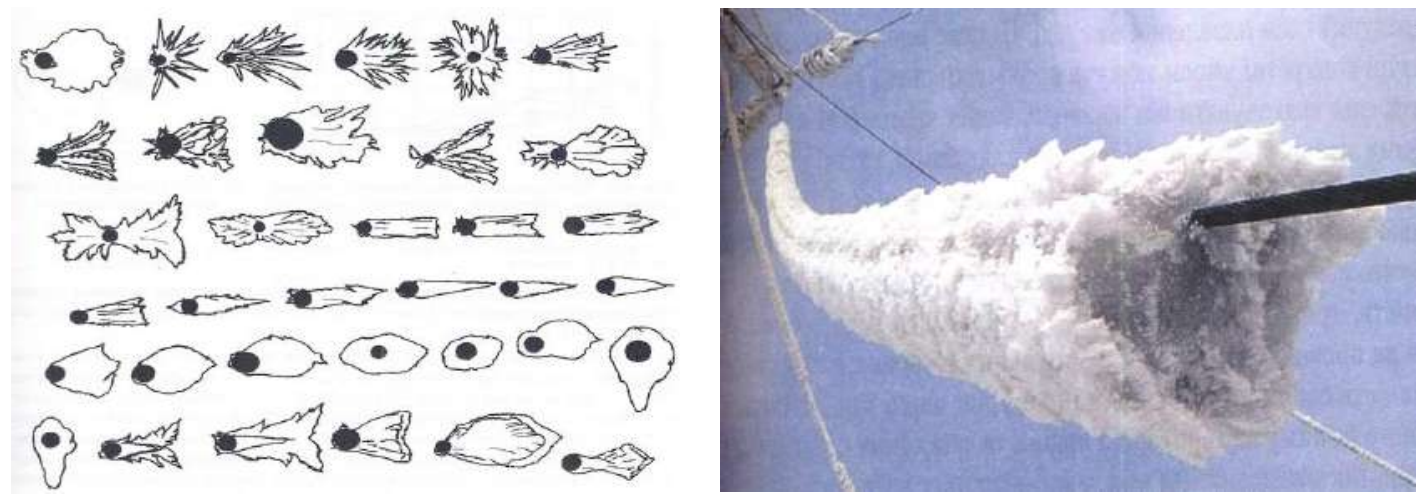

Рисунок 3 - Найхарактерніші форми ожеледно-паморозевих відкладень та загальний вигляд проводу ПЛ з ожеледдю несиметричної форми

Пошкодження проводу, спричинені коливаннями, зазвичай відбуваються в місцях його закріплення або в місцях підвіски на проводі пристроїв зі значною масою, де умови роботи проводу за вібрації особливо несприятливі, і можуть виявлятися в частковому зношуванні поверхні проводу або в послідовному зломі окремих дротів. Зі збільшенням кількості обірваних дротів напруга в дротах, що залишилися непошкодженими, зростає, руйнування набуває зростаючого характеру, поки не відбувається повний обрив проводу.

Програмний пакет SolidWorks - потужний інженерний та дослідницький інструмент, за допомогою відповідних бібліотек якого можна створювати складні динамічні багатовекторні моделі розподілення в часі та просторі багатьох параметрів. Вбудована програма візуалізації дозволяє відслідковувати динаміку зміни контрольованих параметрів та організувати варіативне моделювання для об'єктів, які відрізняються технічними характеристиками (наприклад, геометричні характеристики та просторове положення проводів ПЛ, які перебувають під дією вітру та ожеледних навантажень).

Нижче як приклад наведено послідовність та результати моделювання процесу обтікання потоком повітря проводу ПЛ марки АС-70/11, який перебуває у різних експлуатаційних режимах.

\section{Периий крок. Моделювання проводу ПЛ («оголеного» та з ожеледними відкладеннями)}

На рис. 4 наведено результат побудови моделі перерізу «Перший крок. Моделювання проводу ПЛ («оголеного» та 3 ожеледними відкладеннями)» проводу марки AC-70/11 у середовищі SolidWorks. Зовнішній вигляд та геометричні характеристики моделі проводу цілком відповідають фактичним характеристикам проводу марки АC-70/11, як за кількістю жил, так і за площиною перерізу.

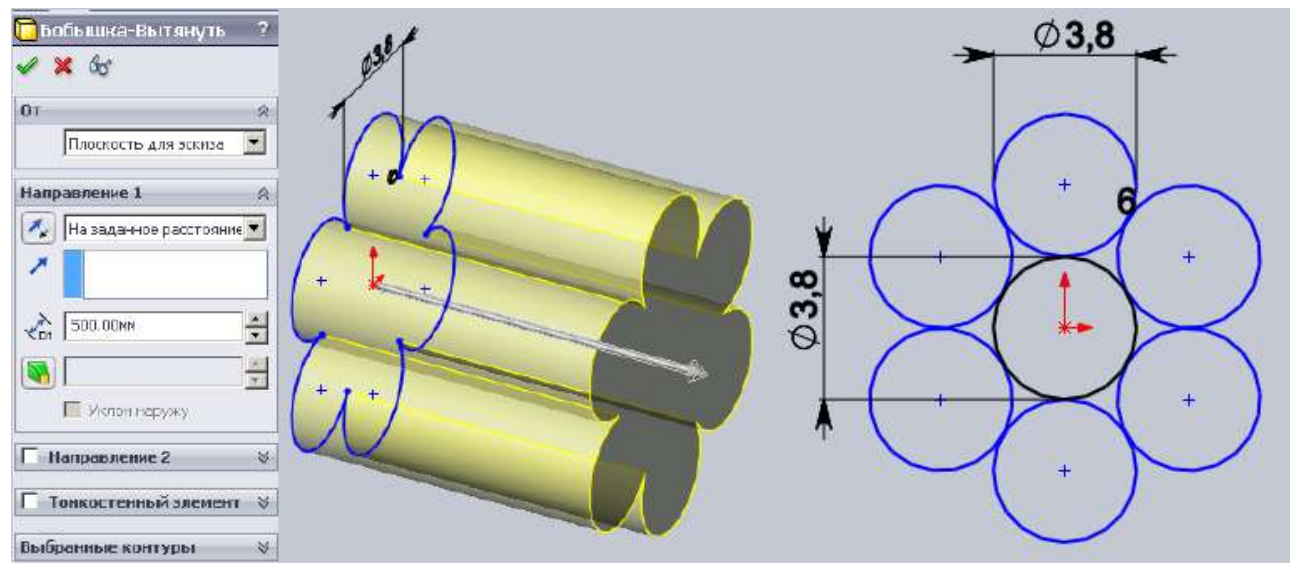

Рисунок 4 - Результат побудови моделі перерізу проводу марки AC-70/11 у середовищі SolidWorks 
Після цього моделюємо провід, вкритий ожеледдю несиметричної форми. Результат побудови моделі перерізу наведено на рис. 5.

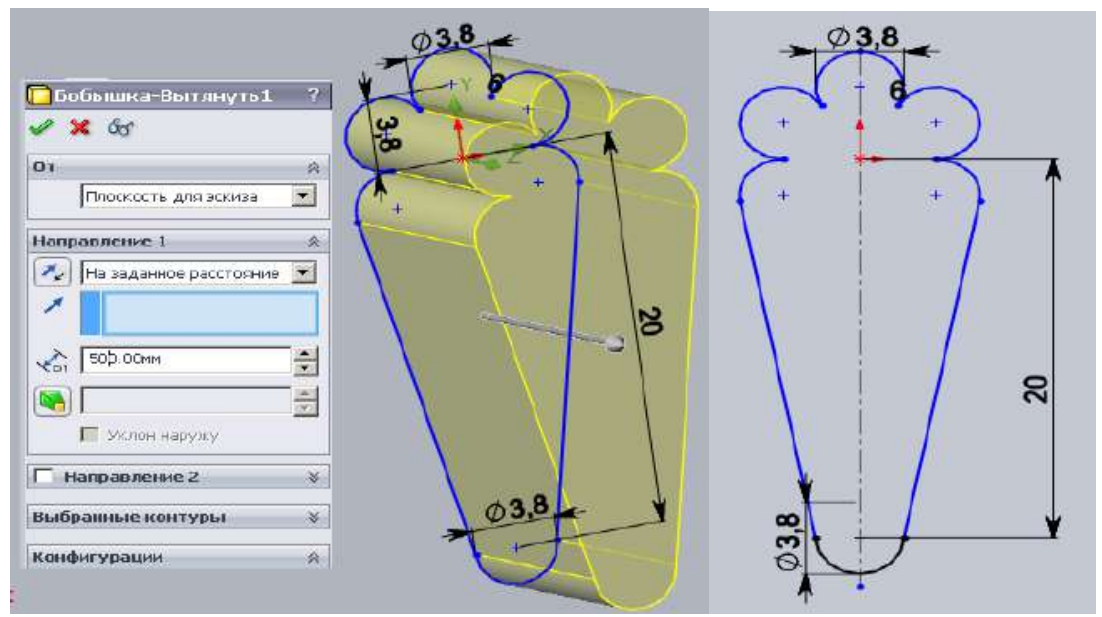

Рисунок 5 - Результат побудови моделі перерізу проводу марки AC-70/11, вкритого ожеледдю несиметричної форми, у середовищі SolidWorks

\section{Другий крок. Моделювання обтікання потоком повітря проводу ПЛ без ожеледі}

Результати моделювання траєкторій обтікання «Перший крок. Моделювання проводу ПЛ («оголеного» та $з$ ожеледними відкладеннями)» проводу марки АC-70/11 потоком повітря наведено на рис. 6, а загальний вигляд розподілення потоків повітря за швидкостями - на рис. 7.

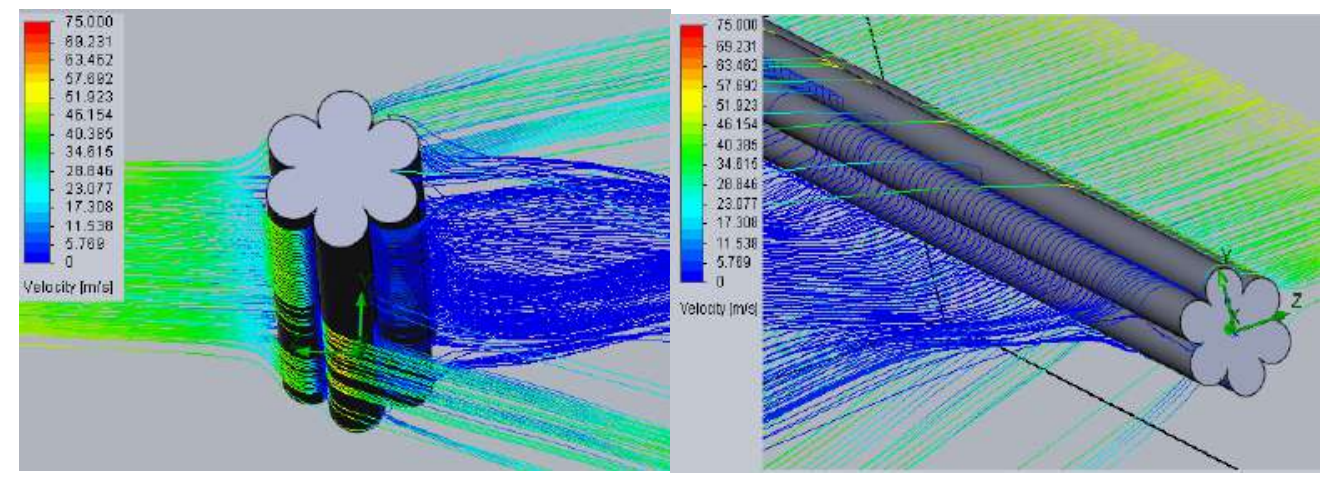

Рисунок 6 - Результати моделювання траєкторій обтікання потоком повітря «голого» проводу

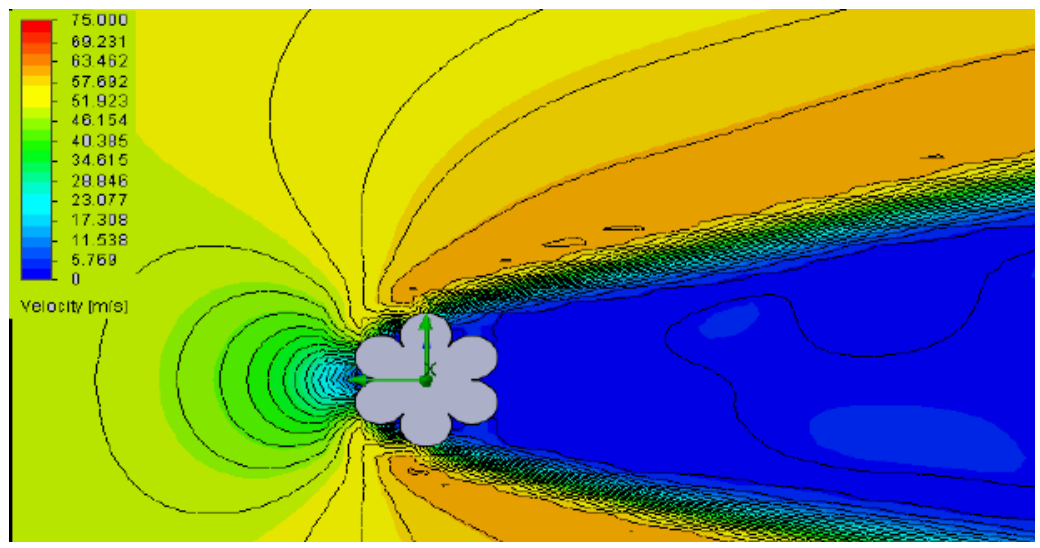

Рисунок 7 - Загальний вигляд розподілення потоків повітря за швидкостями 
ISSN 1813-5420 (Print). Енергетика: економіка, технології, екологія. 2018. № 1

Третій крок. Моделювання обтікання потоком повітря проводу ПЛ з ожеледдю несиметричної форми і.малим кутом відхилення

Результати моделювання траєкторій обтікання наведено на рис. 8 , а загальний вигляд розподілення потоків повітря за швидкостями - на рис. 9.

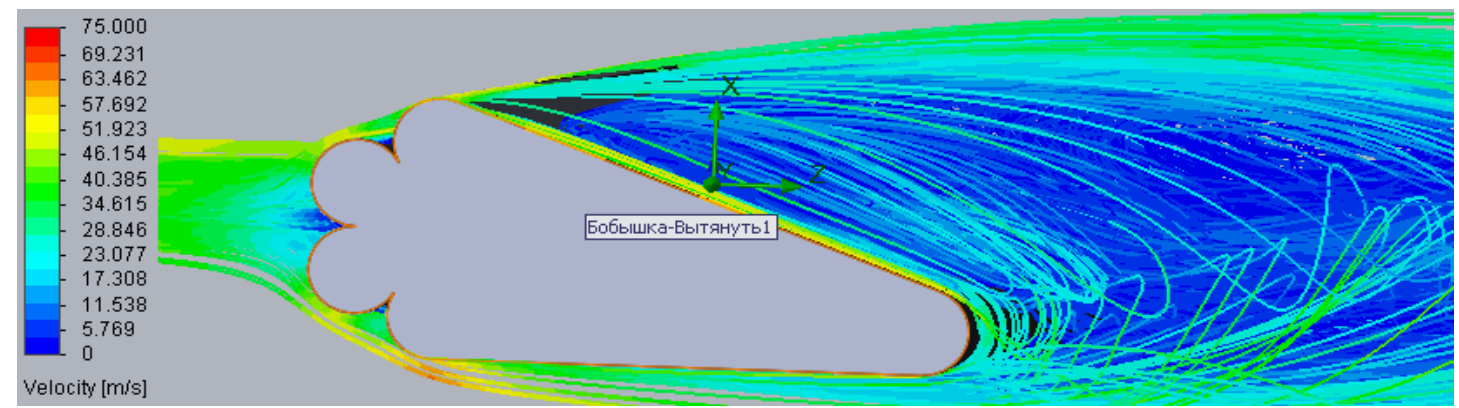

Рисунок 8 - Результати моделювання траєкторій обтікання потоком повітря проводу з ожеледдю

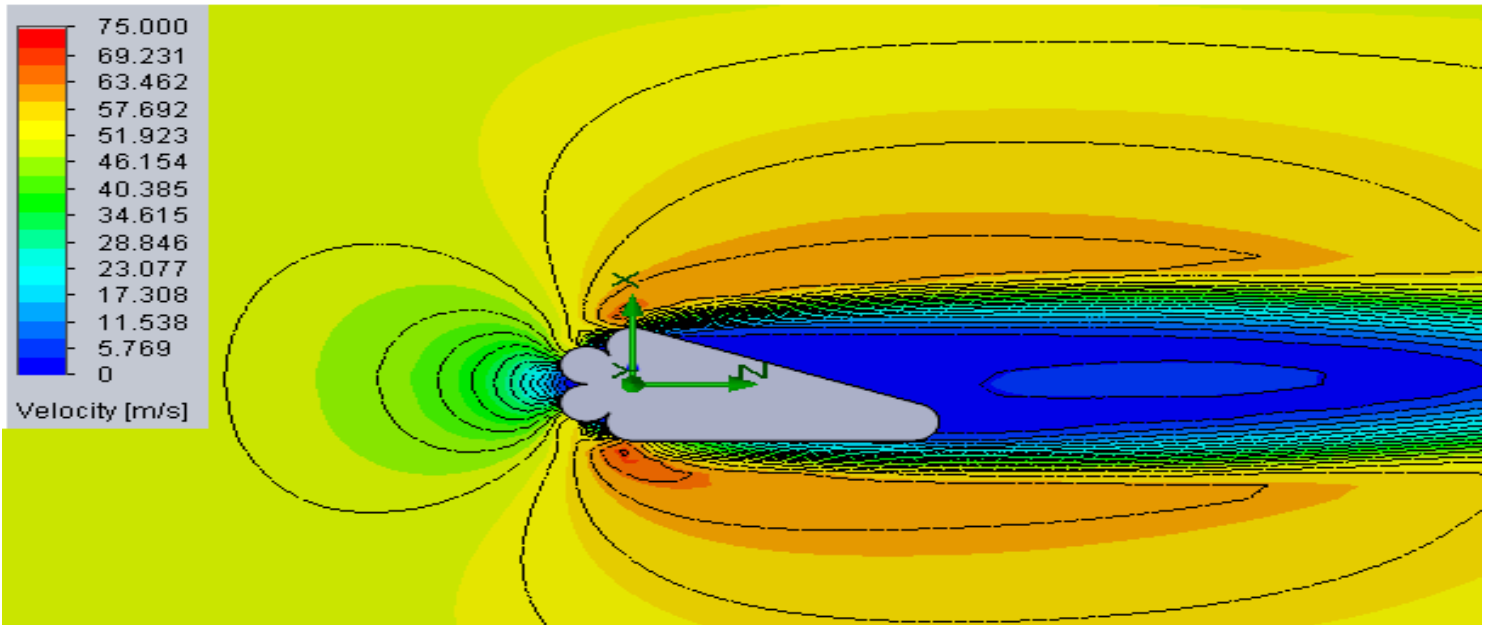

Рисунок 9 - Загальний вигляд розподілення потоків повітря за швидкостями

Четвертий крок. Моделювання обтікання потоком повітря проводу ПЛ з ожеледдю несиметричної форми і великим кутом відхилення

Результати моделювання траєкторій обтікання наведено на рис. 10, а загальний вигляд розподілення потоків повітря за швидкостями - на рис. 11.

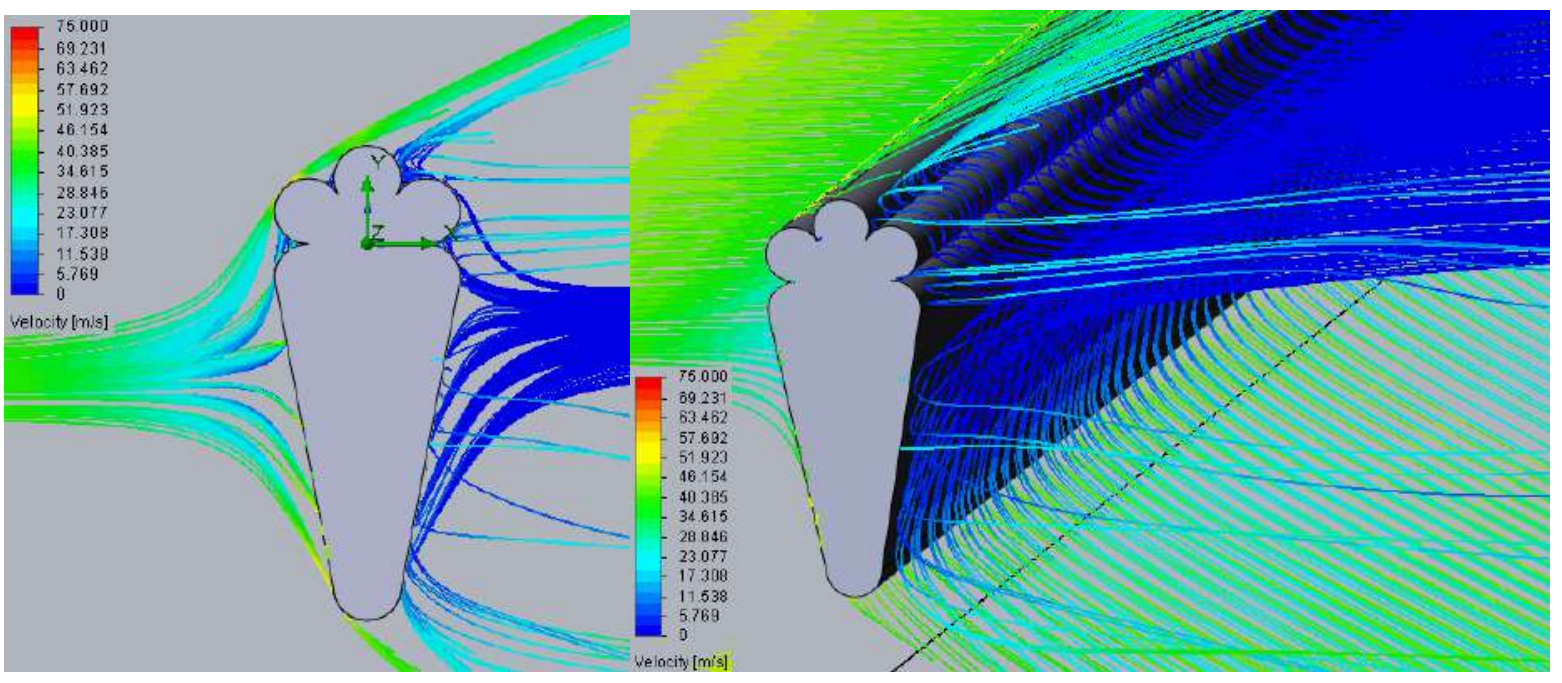

Рисунок 10 - Результати моделювання траєкторій обтікання потоком повітря проводу з ожеледдю 


\section{ISSN 1813-5420 (Print). Енергетика: економіка, технології, екологія. 2018. № 1}

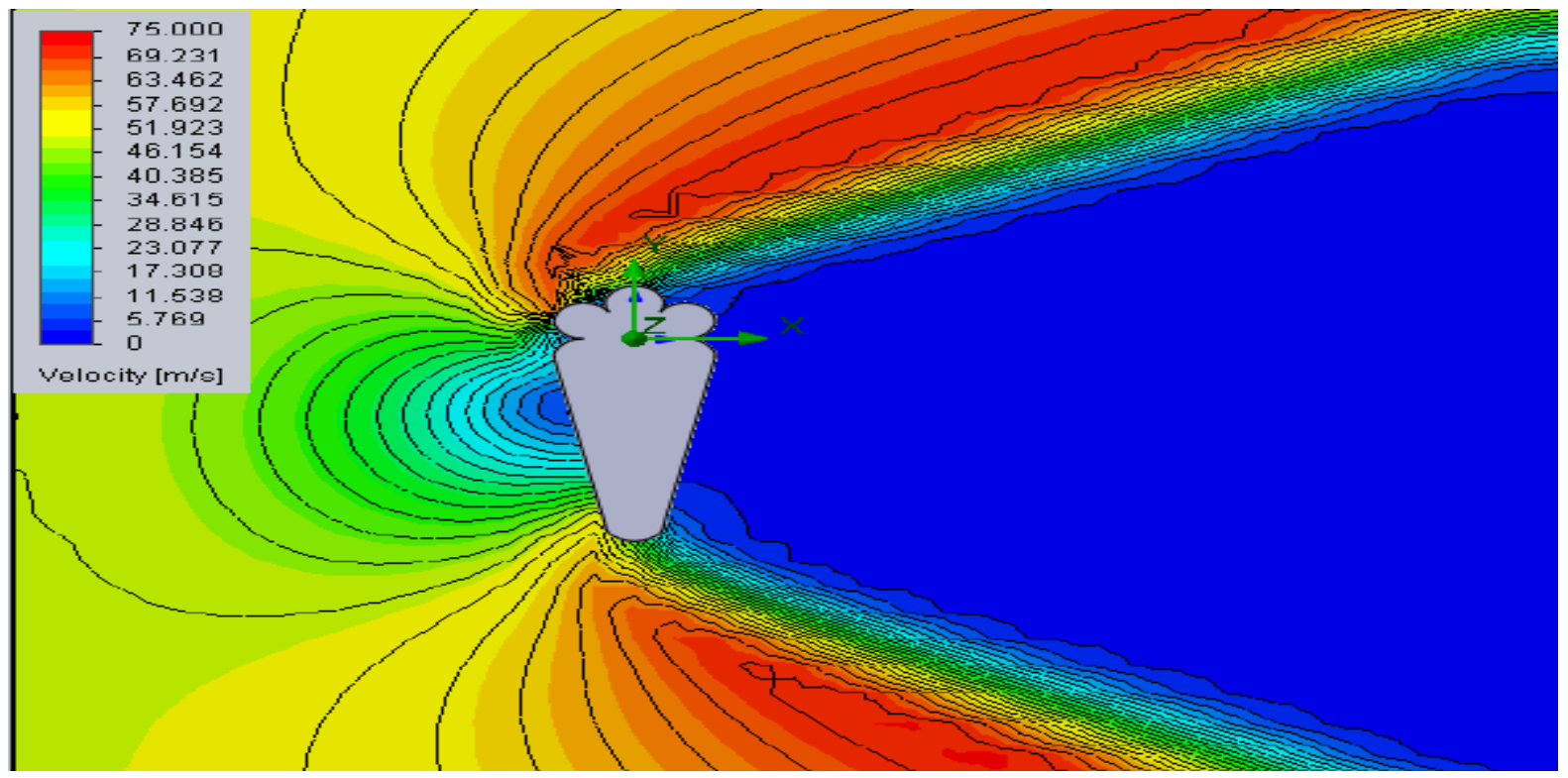

Рисунок 11 - Загальний вигляд розподілення потоків повітря за швидкостями

Висновки Забезпечення надійної роботи повітряних ліній електропередачі - запорука надійної та ефективної роботи систем електропостачання різних класів напруги. Коливання проводів ПЛ під дією вітру негативно впливають на стан проводів, що в подальшому призводить до виснаження матеріалу проводу і з часом до повного його руйнування. Особливо негативно на стан проводів ПЛ впливають ожеледно-вітрові навантаження, що призводять до масштабних аварій зі значними збитками та тривалими перервами електропостачання.

Виникнення коливань проводів ПЛ, що перебувають під дією ожеледно-вітрових навантажень, потребує додаткових досліджень. Ефективним інструментом таких досліджень, крім фізичних макетів та натурних експериментів, є комп’ютерне моделювання, перевагами якого є можливість досліджувати стан проводів ПЛ за різних метеорологічних умов.

Створена динамічна модель обтікання проводу ПЛ марки АС-70/11 із застосуванням програмного пакету SolidWorks дозволяє з високою точністю визначати швидкості та просторову форму потоків повітря, а також відслідковувати динаміку їх переміщення за різних умов експлуатації, що в свою чергу дозволить в подальшому розрахувати амплітуду та форму коливань проводів ПЛ, що перебувають під дією ожеледно-вітрових навантажень.

\section{Список використаної літератури}

1. Казанський С.В. Надійність електроенергетичних систем: навч. посібник / С.В. Казанський, Ю.П. Матеєнко, Б.М. Сердюк. - Київ.: НТУУ «КПІ», 2011. - 216 с. - ISBN 978-966-622-453-1.

2. Крижов Г.П. Ожеледно-вітрові навантаження, галопування проводів повітряних ліній електропередавання та боротьба з ними: довідково-метод. посібник / Г.П. Крижов, Т.Є. Удод, Г.І. Гримуд. - Київ.: «ДП НТУКЦ Аселенерго», 2010. - 456 с. - ISBN 978-966-2003-65-9.

3. СОУ 45.2-00100227-24:2010 Захист проводів і тросів повітряних ліній електропередавання від вітрових коливань (вібрації, галопування, субколивань). Методичні вказівки. - Київ.: КВІЦ. - 2010.

4. ПУЕ-2006. Правила улаштування електроустановок. Розділ 2. Передавання електроенергії. Глава 2.4 Повітряні лінії електропередавання напругою до 1 кВ. Глава 2.5 Повітряні лінії електропередавання напругою вище 1 кВ до 750 кВ. Затв. наказом Мінпаливенерго України від 05.01.2006 р. № 3. - К.: ОЕП «ГРІФРЕ», 2006.

5. ГКД 34.20.507-2003 Технічна експлуатація електричних станцій і мереж. Правила. Затв. наказом Мінпаливенерго України від 13.06.2003 р. № 296. - К.: ОЕП ГРІФРЕ, 2003.

6. Горохов Е.В., Ветровые и гололедные воздействия на воздушные линии электропередачи /Е.В. Горохов, М.И. Казакевич, С.В. Турбин, Я.В. Назим и др. Под ред. Горохова Е.В. - Донецк, 2005. -348 с.

7. Удод Т.Е. Анализ пляски проводов ВЛ (Новые представления о физике процесса). // Семинар стран СНГ «Вопросы проектирования, строительства и эксплуатации ВЛ с учетом перспективы повышения надежности их работы на современном этапе» (МЭС-3). - Москва, 2007. 
8. Горохов Е.В. Эффективность энергетического строительства и эксплуатации в Украине / Е.В. Горохов, Г.И. Гримуд, В.Ф. Мущанов и др. Под ред. Е.В. Горохова и Г.И. Гримуда. - Макеевка, РИО ДонНАСА, 2008. - 172 с.

9. Вибрация и пляска проводов на воздушных линиях електропередачи [Електронний ресурс] Режим доступу: http:/electricalschool.info/main/vl/416-vibracija-i-pljaska-provodov-na.html.

S. Kazanskiy, Cand.Sc. (Eng.), Assoc. Prof ORCID 0000-0002-6113-2600

V. Mossakovskiy, TF ORCID 0000-0002-5096-5957

R. Merkotan, Msc. ORCID 0000-0002-4813-9656

\section{National Technical University of Ukraine «Igor Sikorsky Kyiv Polytechnic Institute» RESEARCHING OF THE OF OVERHEAD TRANSMISSION LINE WIRES OSCILLATIONS} TAKING INTO ACCOUNT OF ICE-WIND LOADINGS

The article in question about reliability increasing of the overhead transmission lines which cross the area with a high probability of increased wind and ice loadings.

It has been shown the need of increasing the operational reliability of the overhead transmission lines as one of the main part of electrical power transmission system. The question of improve of wires oscillation simulation of the overhead line under different ice-wind loading conditions.

It has been shown modeling sequence overhead line wire airflow, type AS-70/11, without talking about coating of ice, and talking about coating of ice of different shape.

It shows the results of modeling which confirm the feasibility to give proper weigh of wind flow force and direction, and coating of ice of different shape. Wind and ice-load are the determining factors in computation the amplitude and frequency of oscillations.

The use of simulation results will significantly improve the operational reliability of the 6-35 $\mathrm{kV}$ overhead transmission lines especially, which cross the area with a high ice-wind loadings.

It shows the expediency of additional studies of the occurrence of complex oscillations of wires with different frequency and amplitude, which arise in the case of ice formation, whose shape is not perfectly cylindrical and significantly affects the variation of the oscillatory process, is substantiated. A particular case of such a study can be spatial modeling of the oscillatory process of the overhead of the transmission line wire, talking about coating of ice of different shape.

Key words: overhead transmission line, wires oscillation, ice-wind loadings, non-stationary simulation.

\section{References}

1. Kazansky S. Reliability of power systems: training aid /S. Kazansky, Y. Mateyenko, B. Serdyuk. - K.: NTUU «KPI», 2011. - P.216 - ISBN 978-966-622-453-1.

2. Kryzhov G. Ice-wind loads, galloping of electric lines of electric lines and fighting them: a reference method. manual / G. Kryzhov, T. Udod, G. Grimyd - Kyiv: «DP NTCC Asselergo», 2010. - 456 p. - ISBN 978966-2003-65-9.

3. SOU 45.2-00100227-24: 2010 Protection of wires and cables of electric power transmission lines from wind oscillations (vibration, galloping, sub-rolling). Methodical instructions. - Kyiv: KVIC. - 2010.

4. REI-2006. Rules for electrical installation. Section 2. Transmission of electricity. Chapter 2.4. Overhead transmission lines up to $1 \mathrm{kV}$. Chapter 2.5 Overhead transmission lines voltage above $1 \mathrm{kV}$ to $750 \mathrm{kV}$. Shuttle By order of the Ministry of Fuel and Energy of Ukraine dated January 5, 2006, № 3. - K.: ORE «GRIFRE», 2006.

5. SKD 34.20.507-2003 Technical operation of electric power stantions and networks. Rules. Shuttle Order of the Ministry of Fuel and Energy of Ukraine dated June 13, 2003. № 296. - K.: OEP «GRIFRE», 2003.

6. Gorokhov E. Wind and glaze effects on overhead transmission lines / E. Gorokhov, M. Kazakevich, S. Turbin, Ya. Nazim and others. Ed. by Gorokhov E. - Donetsk, 2005. - 348 p.

7. Udod T. Analysis of the dance of wires of PL (New ideas about the physics of the process) / Seminar of the CIS countries «Issues of design, construction and operation of overhead lines, taking into account the prospects for improving the reliability of their operation at the present stage» (MES-3). - Moscow, 2007.

8. Gorokhov E. Efficiency of energy construction and operation in Ukraine / E. Gorokhov, G. Grimyd, V. Mushchanov and others. Ed. by E. Gorokhov and G. Grimyd. - Makeevka, RIO DonNASA, 2008. - 172 p.

9. Vibration and dance of wires on overhead power lines [Electronic resource] - Website data: http://electricalschool.info/main/vl/416-vibracija-i-pljaska-provodov-na.html. 
C.B. Казанский, канд. техн. наук, доц. ORCID 0000-0002-6113-2600

В.И. Моссаковський, ассист. ORCID 0000-0002-5096-5957

P.A. Меркотан, магистр ORCID 0000-0002-4813-9656

Национальный технический университет Украины «Киевский политехнический институт имени Игоря Сикорского» ИССЛЕДОВАНИЕ КОЛЕБАНИЙ ПРОВОДОВ ВОЗДУШНЫХ ЛИНИЙ ЭЛЕКТРОПЕРЕДАЧИ С УЧЕТОМ ГОЛОЛЕДНО-ВЕТРОВЫХ НАГРУЗОК

Статья посвящена проблеме повышения надежности воздушных линий электропередачи, расположенных в районах с высокой вероятностью возникновения повышенных ветровых и гололедных загрузок. В статье показана необходимость повышения эксплуатационной надежности воздушных линий электропередачи как одного из основных элементов системы передачи электрической энергии. Рассмотрен вопрос совершенствования построения модели колебаний проводов воздушных линий электропередачи в различных режимах ветровых и гололедных загрузок.

Представлена последовательность моделирования процесса обтекания провода марки АC 70/11 потоком воздуха без учета и с учетом образования гололеда различной формы. Приведены результаты моделирования, которые подтверждают иелесообразность учета силь и направления ветрового потока, а также формы гололеда, которые являются определяющими факторами при определении амплитуды и частоты колебаний. Показано, что использование результатов моделирования позволит существенно повысить эксплуатационную надежность воздушных линий электропередачи, особенно напряжением от 6 до 35 кB, расположенных в районах со значительными гололедно-ветровыми нагрузками.

Обоснована ичелесообразность дополнительных исследований возникновения сложных колебаний проводов с разной частотой и амплитудой, которые возникают в случае образования гололеда, форма которого не является идеально ицлиндрической и существенно влияет на изменение колебательного процесса. Такими исследованиями, в частности, может быть пространственное моделирование колебательного процесса провода в пролете линии электропередачи с учетом гололедных образований различной формы.

Ключевые слова: воздушные линии электропередачи, колебания проводов, гололедно-ветровые нагрузки, динамическое моделирование

Надійшла 22.02.2018

Received 22.02.2018

УДК 621.18.063

A.B. Баранюк, канд. техн. наук, ст. препод., ORCID 0000-0001-6008-6465

A.M. Терех, канд. техн. наук, с. н. с., ORCID 0000-0002-1320-8594

B.А. Янушевский, магистрант, ORCID 0000-0003-0179-1433

Национальный технический университет Украины «Киевский политехнический институт имени Игоря Сикорского»

\section{СFD-МОДЕЛИРОВАНИЕ АЭРОДИНАМИЧЕСКОГО СОПРОТИВЛЕНИЯ ПУЧКОВ ВИНТООБРАЗНЫХ ТРУБ}

Средствами CFD-моделирования проведено исследование аэродинамического сопротивления шахматных пучков винтообразных труб с равноразвитой поверхностью в диапазоне изменения чисел Рейнольдса от $9,5 \cdot 10^{3}$ до $45 \cdot 10^{3}$. Изучены модели пучков с отношениями шагов между трубами $s_{1} / s_{2}=0,46$, 0,92 и 1,83 . Показано, что аэродинамическое сопротивление пучка винтообразных труб с $s_{1} / s_{2}=0,92$ всего на 5\% выше аналогичного гладкотрубного пучка. Предложены расчетные соотношения для определения аэродинамического сопротивления исследованных шахматных пучков однозаходных винтообразных труб с равноразвитой поверхностью. Выявлено, что коэффициент $C_{\mathrm{s}}$ и показатель степени $n$ при числе Рейнольдса в уравнении подобия зависят от шаговых характеристик пучков. Использование винтообразных труб в теплообменниках типа «газ-газ» позволяет увеличить интенсивность теплообмена на (10-30\%) при умеренном росте аэродинамического сопротивления, в результате чего можно существенно улучшить массогабаритные характеристики теплообменных аппаратов.

Ключевые слова: винтообразная труба, равноразвитая поверхность, шахматный пучок, аэродинамическое сопротивление, расчет

(C) А.В. Баранюк, А.М. Терех, В.А. Янушевский, 2018 